\title{
STRUCTURE AND RELATIONSHIPS \\ OF THE UPPER CARBONIFEROUS INSECT, PROCHOROPTERA CALOPTERYX (DIAPHANOPTERODEA, PROCHOROPTERIDAE)
}

\section{By Frank M. Carpenter ${ }^{1}$ and Eugene S. Richardson, JR. ${ }^{2}$}

Prochoroptera calopteryx was described by Handlirsch (1911) from a single specimen in a concretion from the Francis Creek Shale (Pennsylvanian) in northeastern Illinois. Although poorly preserved, the fossil showed several unusual features. Because of these and its very incomplete preservation, the insect's relationships have been decidedly controversial. Fortunately, after a lapse of nearly seventy years following the publication of Handlirsch's account, three more specimens have recently been found in concretions from the same deposit. These additional fossils, which have been turned over to us for study, provide considerably more information about the insect than the type and enable more reliable conclusions about its relations with other Paleozoic insects, even though much of its body structure still remains unknown. It clearly belongs to the extinct order Diaphanopterodea and is only the second species of that order known from Pennsylvanian strata in North America. Descriptive accounts of all four specimens of calopteryx are included below, with a discussion of the relationships of the family Prochoropteridae.

For the opportunity of studying these new specimens we are indebted to Helen and Ted Piecko of Chicago, and Mr. J. J. Fagan of Burbank, Illinois. Handlirsch's type of calopteryx has been placed at our disposal by Jean S. Lawless, Division of Invertebrate Paleontology, Peabody Museum, Yale University. Partial support of this research is gratefully acknowledged to the National Science Foundation, Grant No. DEB 78-09947, F. M. Carpenter, Principal Investigator.

\footnotetext{
'Museum of Comparative Zoology, Harvard University, Cambridge, Massachusetts 02138 .

${ }^{2}$ Field Museurn of Natural History, Chicago, Illinois 60605

Manuscript received by the editor, November 25, 1978.
} 


\section{ORder Diaphanopterodea}

Diaphanopteroidea Handlirsch, 1919, p. 575.

Diaphanopterodea Rohdendorf, 1962, p. 69; Carpenter, 1963, p. 253.

[= Palaeohymenoptera Haupt, 1941, p. 99.]

\section{Farnily Prochoropteridae}

Prochoropteridae Handlirsch, 1911, p. 375.

Fore wing: similar to that of the Elmoidae but with SC extending much farther beyond the origin of RS than in Elmoa; stem of R without a prominent bend at the point of divergence of CUA; cross veins weakly developed, without branching. Hind wing: similar to the fore, so far as known, but relatively broader and with its hind margin more curved; coalescence of RS with MS apparently less than in the fore wing. Thorax large, but prothorax small and conical; head small (from above).

Type-genus: Prochoroptera Handlirsch. A second genus, Euchoroptera Carpenter (1940), from the Pennsylvanian of Kansas (Stanton Formation), also appears to belong to this family; little is known of its wing venation, but the body structures are like those of other Diaphanopterodea.

\section{Genus Prochoroptera Handlirsch}

Prochoroptera Handlirsch, 1911, p. 376.

Since this genus is monospecific, its characteristics can only be suggested. In all probability the coalescence of MA with RS and the distal forking of MP are in this category. Prochoroptera differs from Euchoroptera in having the branching of RS pectinate, instead of dichotomous.

Type-Species: Prochoroptera calopteryx Handlirsch.

\section{Prochoroptera calopteryx Handlirsch}

Figures 1-3

Prochoroptera calopteryx Handlirsch, 1911, p. 376; 1919, p. 586; 1920, p. 172. Haupt, 1941, p. 99. Laurentiaux, 1953, p. 444. Carpenter, 1940, p. 638; 1947, p. 45; 1963, p. 248.

The fore wing is known to a length of $20 \mathrm{~mm}$; estimate of complete length (based on Euchoroptera), $36 \mathrm{~mm}$; maximum width, $6 \mathrm{~mm}$. Hind wing: known to a length of $20 \mathrm{~mm}$; maximum width, 6 


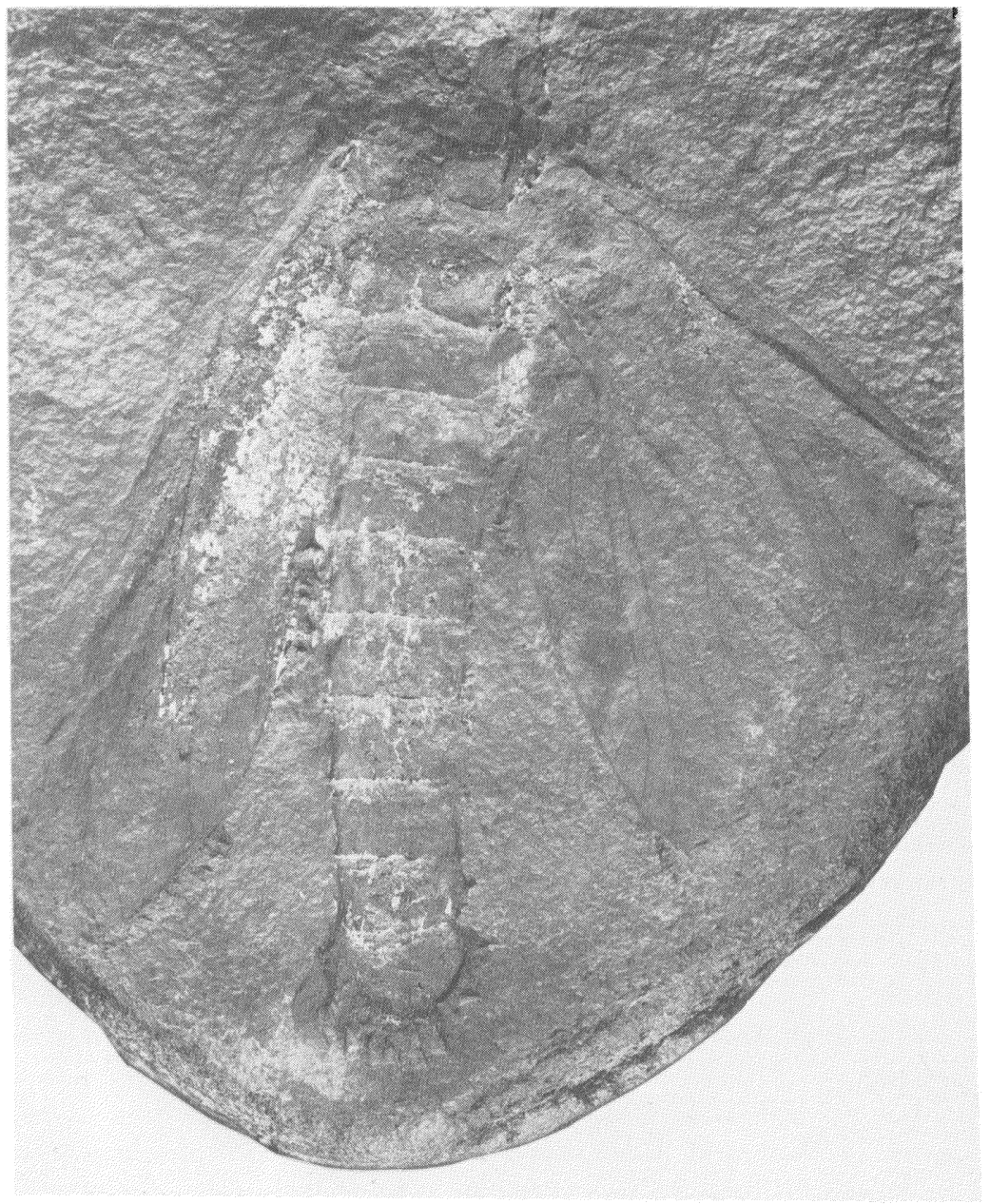

Figure 1. Prochoroptera calopteryx. Photograph of reverse of specimen HTP $12523(\times 3.8)$. 
$\mathrm{mm}$. The details of venation are shown in figure 2. Body length, from front of mesothorax to end of abdomen, $25 \mathrm{~mm}$; length of abdomen, 18-19 mm; width, 4-5 $\mathrm{mm}$.

Holotype: no. YPM67, Peabody Museum, Yale University (obverse and reverse).

As shown in Handlirsch's figure, this fossil includes the thorax, abdomen, and parts of both pairs of wings, which rest obliquely backward. His figure of the wings is essentially accurate, although his attempted restoration of the complete wing turns out to be incorrect, at least to the extent that we now know it. The body is also satisfactorily represented in his figure, although the prothorax is too large. The abdominal segments of this specimen possess paired lateral expansions, apparently strongly sclerotized and similar to those present in at least some Palaeodictyoptera. Handlirsch's figure depicts these as membranous areas bordering the terga, but there is nothing in the fossil to support that interpretation. The 9th abdominal segment bears a pair of longitudinal ridges, converging distally, as shown in Handlirsch's figure. These are almost certainly the basal portions of the valves forming the ovipositor. Cerci are not preserved. ${ }^{3}$ The dimensions of this specimen are as follows: fore wing, length (as preserved), $20 \mathrm{~mm}$; width uncertain; hind wing, length (as preserved), $20 \mathrm{~mm}$. Body length (from front of mesothorax to end of abdomen), $25 \mathrm{~mm}$; pterothorax, length, $6.3 \mathrm{~mm}$; width, maximum, $6 \mathrm{~mm}$; abdomen, length, $18 \mathrm{~mm}$; width, maximum (3rd segment), $4.5 \mathrm{~mm}$; prothorax, length, $3.5 \mathrm{~mm}$; head absent.

The three recently discovered specimens of calopteryx are as follows:

1. No. JJF-IL11-007, collected by J. J. Fagan in Pit 11 (strip mine in Will and Kankakee Counties, 3 to 5 miles south of Braidwood, Illinois). ${ }^{4}$ This specimen is preserved in almost the same position as the type. The prothorax and the wing veins are clearer than in the type. Its dimensions are as follows: fore wing, length (as

\footnotetext{
${ }^{3}$ Most of the "whole" specimens of insects preserved in these concretions lack the distal parts of the wings and the distal anterior and posterior appendages, such as antennae and cerci. The insect's body is ordinarily in the center of the concretion, which is usually too small to include the distal portions of these appendages.

${ }^{4} \mathrm{Mr}$. Fagan has now deposited this specimen in the Field Museum of Natural History, where it bears the number PE 25667.
} 


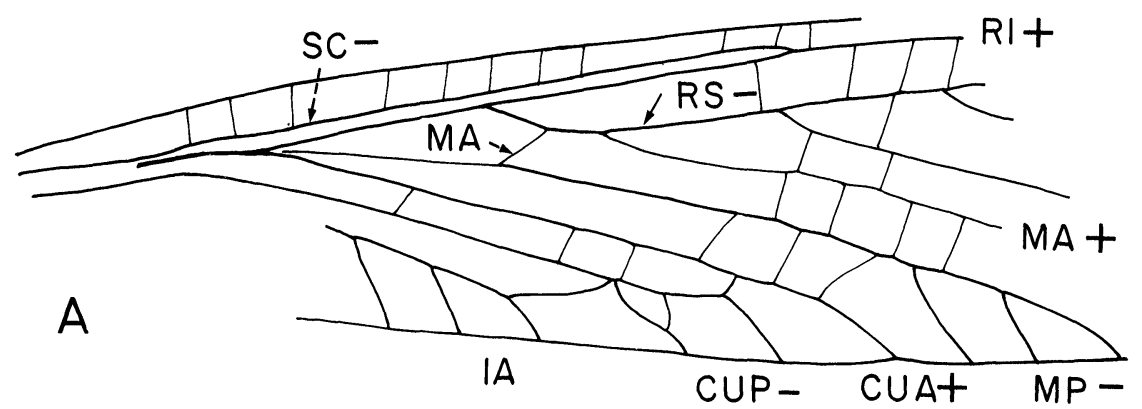

B

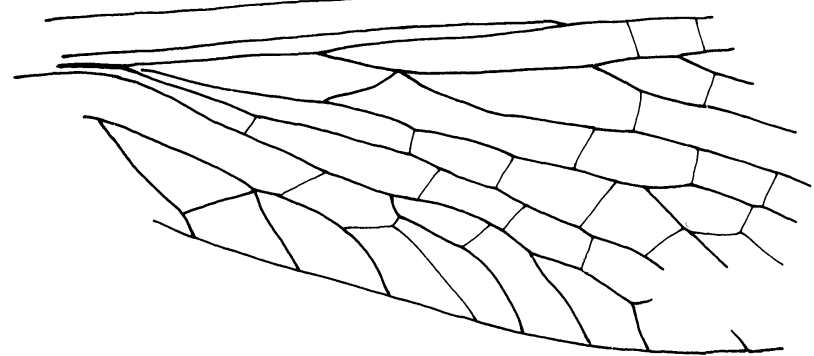

Figure 2. Prochoroptera calopteryx. Drawing of fore and hind wings, as known; based mainly on specimen HTP 12523, with some details added from the holotype and specimen JJF 1L11-007. SC, subcosta; R1, radius; RS, radial sector; MA, anterior media; MP, posterior media; CUA, anterior cubitus; CUP, posterior cubitus; $1 \mathrm{~A}$, first anal vein; + , convex vein; - , concave vein.

preserved), $18 \mathrm{~mm}$; width, $6 \mathrm{~mm}$; hind wing, length (as preserved), $18 \mathrm{~mm}$; width, $6 \mathrm{~mm}$. Body length (from front of mesothorax to end of abdomen), $25 \mathrm{~mm}$; pterothorax, length, $6.3 \mathrm{~mm}$; width, $4.8 \mathrm{~mm}$; abdomen, length $19 \mathrm{~mm}$; width, $4.8 \mathrm{~mm}$; prothorax, length, $2.5 \mathrm{~mm}$; width at posterior edge, $3 \mathrm{~mm}$; head absent.

2. No. HTP 12523, Helen and Ted Piecko collection. This is the best specimen known. The obverse half represents a ventral view of the insect and the reverse (figure 1), a dorsal view. 5 The wings,

'In our terminology, the obverse is the counterpart that shows the topography of the veins as seen on the dorsal surface of the living insect (i.e., SC, concave; R1, convex, etc.); the reverse shows the veins in the opposite topography. Generally speaking, the reverse shows the dorsal surface of the insect, and the obverse shows the ventral surface. 
pterothorax, and abdomen are especially clear, but the prothorax and head are not preserved. The wings on one side, although lacking the apical portions, are very clearly preserved; those on the other side are twisted and folded together. Widely spaced pits in the impressions of the veins and cross veins indicate the original presence of trichia or small setae. The segmentation of the abdomen is especially clear and the lateral extensions of the segments, mentioned above in the type, are faintly preserved in the obverse half of the fossil. Also, in that counterpart, which shows the ventral view of the abdomen, the bases of the ovipositor valves can be seen in the 8th and 9th segments. The ovipositor appears to be about 5 $\mathrm{mm}$ long before disappearing at the edge of the concretion. The cerci are not preserved. The following are the dimensions of this fossil: fore wing (as preserved), $15 \mathrm{~mm}$; width, uncertain; hind wing, length (as preserved), $15 \mathrm{~mm}$; width, $6 \mathrm{~mm}$. Body, length (from front of mesothorax to end of abdomen), $25 \mathrm{~mm}$; pterothorax, length, 5 $\mathrm{mm}$; width, $4.8 \mathrm{~mm}$; abdomen, length, $18.5 \mathrm{~mm}$; width, maximum, $4.6 \mathrm{~mm}$.

3. No. HTP 415, Helen and Ted Piecko collection. This is a poorly preserved specimen, resting in the same position as the previous one. The venation is clear enough for identification of the species, and the prothorax and even the head, which is not shown in other specimens, are discernible. Neither the ovipositor nor the cerci are visible. The dimensions of this specimen are as follows: fore wing (as preserved), $20 \mathrm{~mm}$; width, uncertain; dimensions of hind wing uncertain. Body length (from front of mesothorax to end of abdomen), $25 \mathrm{~mm}$; pterothorax, length, $6 \mathrm{~mm}$; width, maximum, 4 $\mathrm{mm}$; abdomen, length, $20 \mathrm{~mm}$; maximum width, $4.5 \mathrm{~mm}$; prothorax, length, $3.3 \mathrm{~mm}$; posterior width, $2.5 \mathrm{~mm}$; anterior width, 1.5 $\mathrm{mm}$; head, length, $3 \mathrm{~mm}$; width $3 \mathrm{~mm}$. The head as preserved shows somewhat protuberant eyes; the head is obviously seen in dorsal view, with no indication of the beak.

\section{Discussion of Structure}

The wings of calopteryx, as far as they are known at present, are shown in figure 2, which is based mainly on specimen HTP 12523, with some details added from the other specimens. The figure shows more of the basal parts of both wings than was known to Handlirsch. The homologies of the veins are obvious, the convexities and concavities being clearly preserved. Handlirsch (1911) confused MA 
with a branch of the media, but his interpretations were the conventional ones at the time. In all four specimens the amount of coalescence between MA and RS is distinctly less in the hind wing than in the fore wing, but in other respects the venational patterns are nearly identical, so far as they are known. The shape of the hind wing, as preserved, suggests that it may have been slightly shorter than the fore wing, the hind margin having a greater curvature. The fore wing was apparently somewhat more elongate than indicated in Handlirsch's figure.

Figure 3, showing all of the known parts of the insect, is based mainly on HTP 12523 , with the prothorax and head as preserved in HTP 415. The wings have been added to the figure to show their size relative to the body, which appears to be surprisingly robust compared to the wings (See figure 1). The prothorax, which is preserved in HTP 415 and the holotype, is clearly conical in shape and unusually small with respect to the rest of the thorax. The

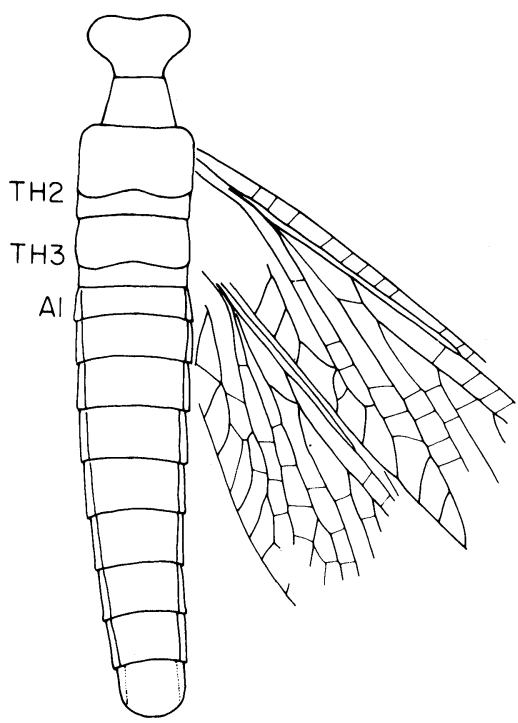

Figure 3. Prochoroptera calopteryx. Drawing of wings and body, as known; based mainly on specimen HTP 12523 (reverse) with prothorax and head added from specimen HTP 415. TH2, mesothorax; TH3 metathorax; A1, first abdominal segment. 
outline of the head is faintly indicated in specimen HTP 415. Handlirsch's drawing (1911) of the type includes a suggestion of the head or part of it, but we have been unable to discern the structure that he has drawn. However, the head as shown in specimen HTP 415 is very small with respect to the rest of the insect, although of course the head as preserved in the fossil is seen from above and does not show its full length. The meso- and metathorax, on the other hand, appear large relative to the rest of the insect. The abdominal segments are virtually homonomous, with only a slight reduction in the width posteriorly.

\section{Affinities of the Prochoropteridae}

Opinions of the affinities of calopteryx, based on the type, have been diverse. Handlirsch $(1911,1919,1920)$ considered it to belong to the Megasecoptera. Carpenter (1940), following the discovery of another and apparently related Pennsylvanian insect (Euchoroptera longipennis), concluded that the family Prochoropteridae had close affinities with the Permian family Asthenohymenidae, then considered to be the most highly specialized of the Megasecoptera. However, Haupt (1941), basing his conclusions on Handlirsch's brief account of Prochoroptera, designated a new order, Palaeohymenoptera, for the farmily Prochoropteridae, assigning it to his "Legion Hymenopteroidea", which also included the Hymenoptera. Unaware of that publication ${ }^{6}$ Carpenter $(1947,1954)$ proposed that the families Prochoropteridae and Diaphanopteridae (Commentry, France), along with two other Permian families, be placed in a separate suborder of the Megasecoptera. However, Rohdendorf in 1962 adopted the ordinal name Diaphanopterodea for that series of families, since the taxon had been named by Handlirsch (1919) for the Diaphanopteridae. That term has subsequently been generally accepted.

The order Diaphanopterodea is now recognized as belonging to the Palaeoptera and as allied to the Palaeodictyoptera and Megasecoptera, all of their members possessing haustellate mouthparts and long cerci. Alone in this series, however, the Diaphanopterodea had the ability to "fold" their wings at rest along the abdomen. The

${ }^{6}$ The journal containing Haupt's 1941 paper (Zeitschrift für Naturwissenschaften, Halle) was not received by the library at Harvard University until January, 1958. 
most distinctive feature of their venation is the coalescence of CUA and $M$ basally, and, except in the Diaphanopteridae, the coalescence of CUA and $M$ further basally with R. In all the families of the order, $M$ appears to arise at the point of divergence of $R$ and CUA.

Although the body structure of Prochoroptera is very incompletely known, the wing venation clearly shows the diagnostic features of the order Diaphanopterodea, and of course, as noted above, in all known specimens the wings are folded along the abdomen. However, the position of the Prochoropteridae within the order is still uncertain. As far as known, the most obvious evolutionary changes within the Diaphanopterodea are the narrowing of the wing base and the consequent increased coalescence of MA with RS and ultimately with R itself (See Carpenter, 1963, plate 10, figs. 1-6). However, it now seems probable that these changes occurred independently within several lines of the order (Kukalova-Peck, 1974). As a result, diagnoses of some families are very difficult to make, especially of those in which the wings are not completely known, such as the Prochoropteridae. However, it seems advisable to retain the family Prochoropteridae as valid and as distinct from such Permian families as Elmoidae and Martynoviidae on the basis of its venational features as presently known.

\section{REFERENCES}

CARPENTER, F. M.

1940. Carboniferous insects from the Stanton Formation, Kansas. AMER J SCI 238: 636-642.

1947. Lower Permian insects from Oklahoma. Part 1. Introduction and the orders Megasecoptera, Protodonata, and Odonata. PROC AMER ACAD ARTS SCI 76: 25-54.

1954. Extinct families of insects, in Classification of Insects (C. T. Brues, A. L. Melander, and F. M. Carpenter). BULL MUS COMP ZOOL 108: 777-827.

1963. Studies on Carboniferous insects from Commentry, France. Part V. The genus Diaphanoptera and the order Diaphanopterodea. PSYCHE 70: 240-256.

Handirsch, A.

1911. New Paleozoic insects from the vicinity of Mazon Creek. AMER J SCI 31: 297-377.

1919. Revision der Paläozoischen Insekten. DENKSCHR ACAD WISS 96: 1-82.

1920. Palaeontologie, in Handbuch der Entomologie (ed. C. Schröder) (3) 7: 117-306. 
HAUPT, H.

1941. Die altesten geflugelten Insekten und ihre Beziehungen zur Fauna der Jetztzeit. ZEIT NATURWISS HALLE 94:60-121.

Kukalova-Peck, J.

1974. Wing-folding in the Paleozoic insects of the order Diaphanopterodea (Palaeoptera), with a description of new representatives of the Elmoidae. PSYCHE 81: 315-333.

1974b. Pteralia of the Paleozoic insect order Palaeodictyoptera, Megasecoptera, and Diaphanopterodea (Palaeoptera). PSYCHE 81: 416-430.

LAURENTIAUX, D.

1953. Classe des insectes, in Traité de Paleontologie (ed. J. Piveteau) 3: 397-527.

ROHDENDORF, B. B., et al.

1962. Osnovi paleontologii [Principles of Paleontology], Moscow (ed. B. B. Rohdendorf), Arthropoda: Tracheata and Chelicerata. Pp. 1-560. 

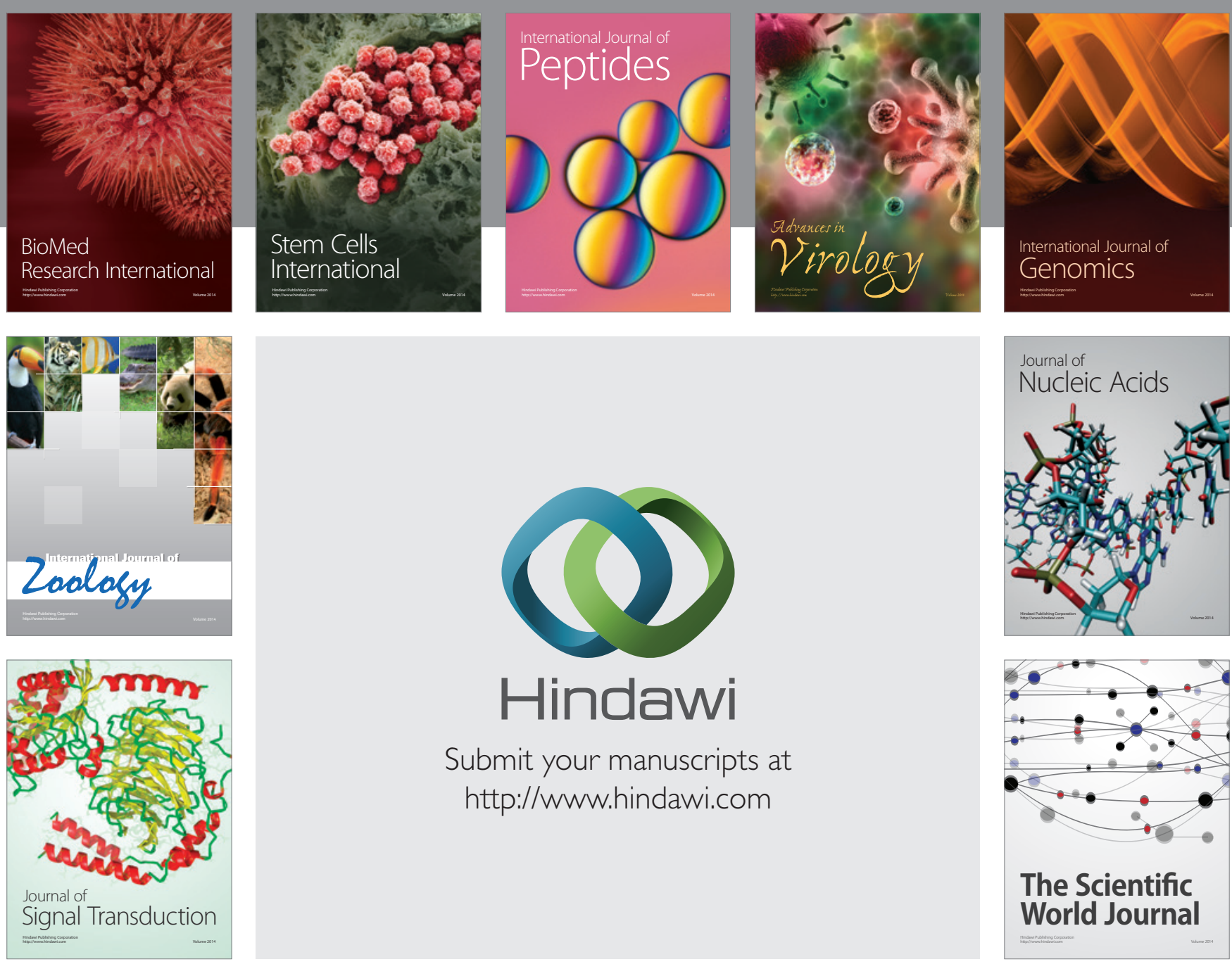

Submit your manuscripts at

http://www.hindawi.com
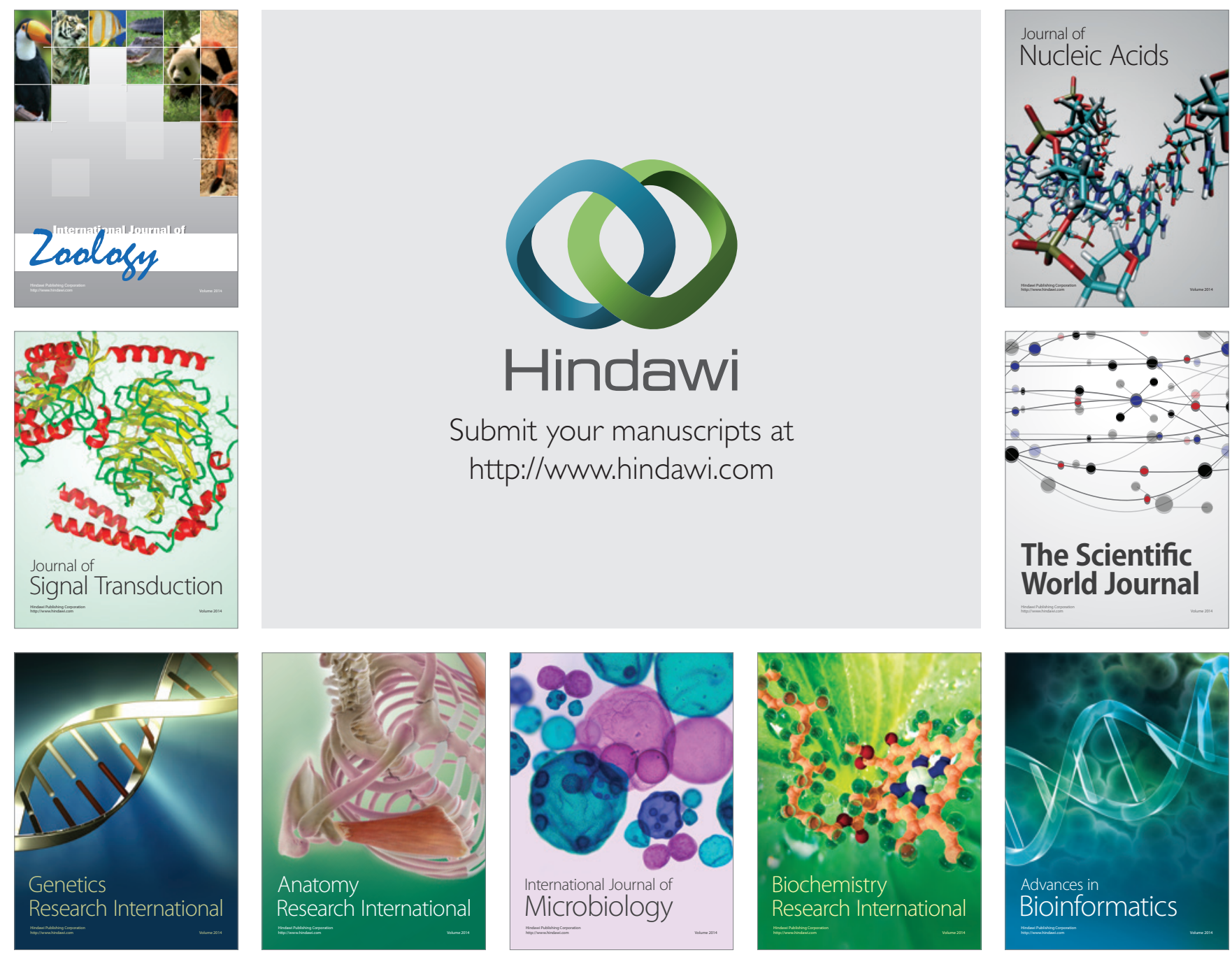

The Scientific World Journal
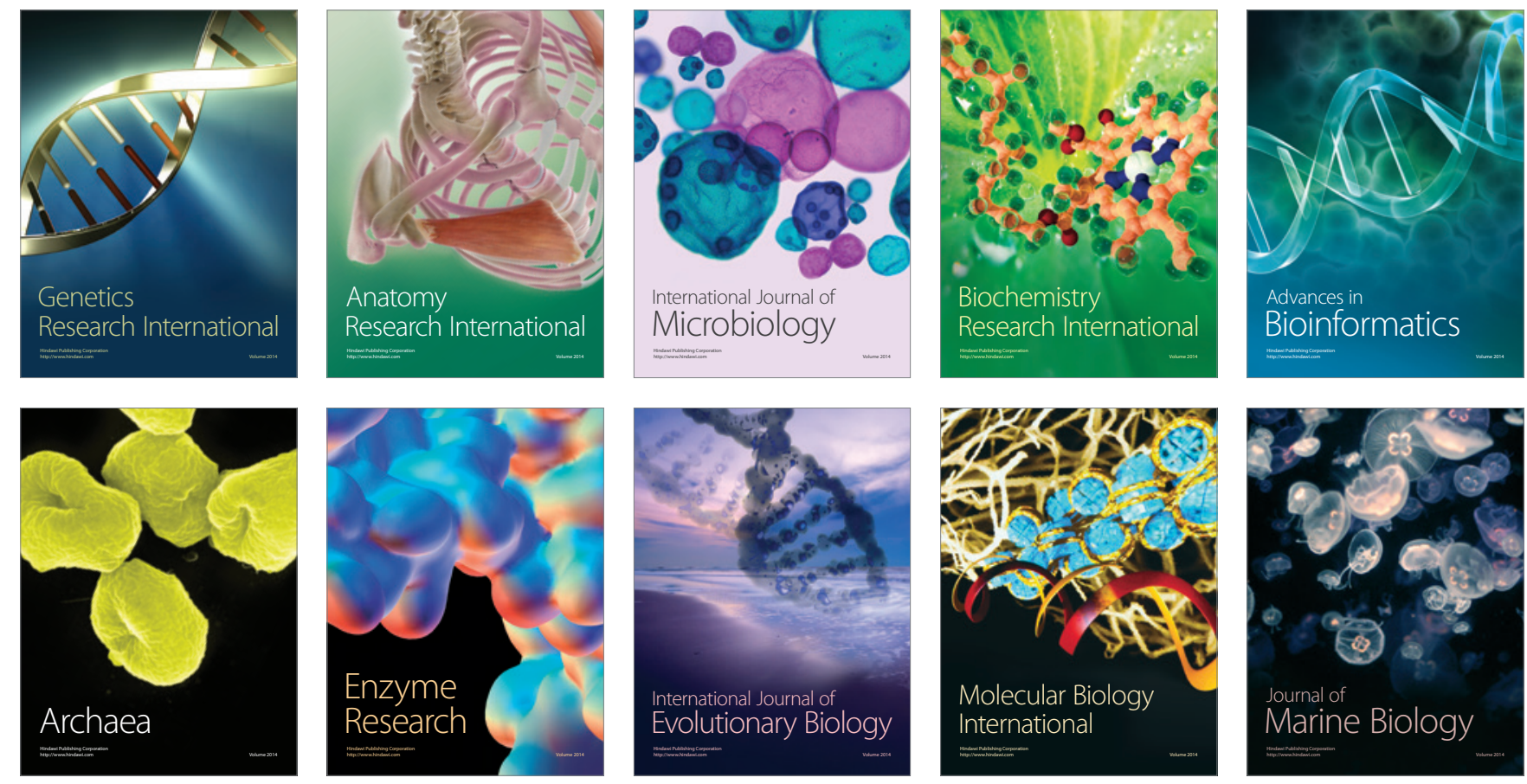